Çukurova Üniversitesi Mühendislik Mimarlık Fakültesi Dergisi, 31(1), 323-336 ss., Haziran 2016

Çukurova University Journal of the Faculty of Engineering and Architecture, 31(1), pp. 323-336, June 2016

\title{
Denizden Su Alma Yapısı ve Binası Performans Analizi ve Güçlendirilmesi
}

\author{
Gökhan GÜRSOY*1, Hüseyin R. YERL $\dot{I}^{1}$ \\ ${ }^{1}$ Çukurova Üniversitesi, Mühendislik Mimarlık Fakültesi, İnşaat Mühendisliği Bölümü, Adana
}

Geliş tarihi: 01.02.2016 Kabul tarihi: 14.03.2016

\begin{abstract}
Özet
Depreme karşı güçlendirme çalışmalarında mevcut yapıların modellenebilmesi için tahribatlı testler büyük önem arz etmektedir. Mevcut yapı malzeme özellikleri modelleme çalışmalarının doğru sonuç vermesini sağlamaktadır. Bu çalı̧̧mada Rus standartlarına göre tasarlanmış ve 1974 yılında yapımı tamamlanmış olan pompa binası ele alınmıştır. Bina; denizden su alma yapısı, su kamaraları, pompa temelleri, betonarme taşıyıcı sistem ve çelik çatıdan teşkil edilmiştir. Mevcut yapı analizi için zemin sondaj çalışmaları yapılmış, dalgıç marifeti ile video ve fotoğraflar çekilmiş, karot numuneleri alınmış, donatıların örnekleme metodu ile çap ve adet kontrolleri yapılmıştır. Alınan ölçüm sonuçlarından hareketle yapının mevcut durumu paket programlar ile modellenerek analiz edilmiştir. Yapılan analizden elde edilen sonuçlara göre gerekli kesit artışları tespit edilmiş ve uygulanması gereken güçlendirmeler projelendirilerek gerekli yapı elemanlarında uygulanmıştır.
\end{abstract}

Anahtar Kelimeler: Yapıların depreme karşı güçlendirmesi, Yapısal deprem mühendisliği, Yapı eleman ve sistemlerinin analizi

\section{Performance Analysis and Strengthening of Water Intake Structure and Building}

\begin{abstract}
Destructive tests have much importance for modelling existing structures of the studies of the strengthening for the earthquake. Existing building materials properties provide the accuracy of the modeling study. In this study, The Pump House which was designed according to the Russian standarts and which was completed construction in 1974 is discussed. Sea Water Intake Buildings has been formed from waterpools, pumps, reinforced concrete system and steel roof. For analysis of the existing structure; ground drilling work was done, video and photos taken with divers ingenuity, core samples were taken and the pieces of rebar diameter were examined. The structure was modelled according to the results by

* Yazışmaların yapılacağı yazar: Gökhan GÜRSOY, Çukurova Üniversitesi, Mühendislik-Mimarlık Fakültesi, Inşaat Müh. Bölümü, Adana.eng.gursoy@gmail.com
\end{abstract}


using computer softwares. Obtained results from the analysis determined by increases in the required section. According to the results the necessary work to strengthen the structure were applied and described by prepared projects.

Keywords: Seismic retrofit of structures, Structural earthquake engineering, Analysis of structural elements and systems

\section{GİRIS}

Teknolojideki hızlı gelişmeler inşaat mühendisliğinde de önemli aşamaların alınmasını sağlamıştır. Bu gelişmelerden en dikkat çekici olanlarından bir tanesi de yapının mevcut durumunun incelenmesi konusunda geliştirilen yöntemlerdir.

Mevcut yapıların deprem performansının tespit edilebilmesi için incelenen yapının bütün bileşenleri ile yeniden modellenmesi gerekmektedir. Bu aşamada incelenen yapının uygulama projelerine başvurulmakta eğer projelere ulaşılamıyorsa röleve çalışmaları yapılmaktadır. Kesit ve ölçülerin projelerden okunmasının ardından malzeme özelliklerinin tespiti için deneylerin yapılması gerekmektedir. $\mathrm{Bu}$ çalışmaları tahribatlı ve tahribatsız olarak ikiye ayırabiliriz. Tahribatlı muayenede yapı üzerinden karot numunesi alınarak ilgili standartlar doğrultusunda basınç testine tabi tutulmakta ve yıllar içerisinde kesit özelliğinde bir değişme olup olmadığı tespit edilmektedir.

Sahada yapilan muayeneler sonucunda elde edilen veriler bilgisayar ortamında girilerek, paket programlar yardımı ile analiz edilmektedir. Analiz sonuçlarına göre yapının performansı yorumlanmakta ve gerekli güçlendirme tekniğine karar verilmektedir. Yapının mevcut malzeme özelliğine göre; mantolama, karbon fiber, çelik takviye gibi güçlendirme teknikleri uygulanabilmektedir.

\subsection{Tesis Hakkında Teknik Bilgiler}

333 No.lu Deniz Suyu Pompa İstasyonu ve $\mathrm{Su}$ Kamaraları, İskenderun Demir Çelik A.Ş. (İSDEMİR) fabrikasında kullanılan soğutma suyunu temin etmek için inşa edilmiştir. Fabrika,
Hatay iline bağlı İskenderun ilçesinde bulunmaktadır.

Söz konusu bina ve su kamaraları 1971 yılında geçerli olan Rus (GOST) şartnamelerinde verilen tasarım kriterlerine göre hazırlanmış ve binanın bu kriterlere uygun olarak inşa edildiği kabul edilmiştir. Aşağıda mevcut yapıda kullanılan Rus standartı karşılaştırmaları yer almaktadır:

\begin{tabular}{|c|c|}
\hline Beton Sinıfları & Çelik Çekme Çubuğu (Akma) \\
\hline B250 - C20 & $\mathrm{AI}: 2400 \mathrm{~kg} / \mathrm{cm}^{2}$ \\
\hline B300 - C25 & AII:3000 kg/ $\mathrm{cm}^{2}$ \\
\hline B350 - C30 & AIII: $4000 \mathrm{~kg} / \mathrm{cm}^{2}$ \\
\hline
\end{tabular}

Denizden su alma tesisi, enerji tesislerinde kurulu olan buhar türbini ve turbo körük kondenserlerinde yoğuşturucu akışkan olarak kullanılan deniz suyunu sağlamaktadır. Ayrıca yaz aylarında merkezi soğutma istasyonuna kondenser soğutma suyu olarak deniz suyu göndermektedir.

Deniz suyu pompa istasyonunda her biri $11,000 \mathrm{~m}^{3}$ /saat kapasiteli, çalışma basıncı 3,8 bar olan 8 adet pompa ve 1 adet yüksek fırın projesi kapsaminda kurulumu yapilan 7,500 $\mathrm{m}^{3} /$ saat kapasiteli 4,2 bar basincinda pompa bulunmaktadır. Mevsim şartlarına ve üretime bağlı olarak 4-6 adet pompa çalışmaktadır.

Tesis havuz yapısı ile deniz arasında yaklaşık 100 $\mathrm{m}$ uzunluğunda üçlü menfez bulunmaktadır. $\mathrm{Bu}$ kanal yardımı ile deniz suyu cazibesi ile tesise gelmekte ve pompa marifeti ile işletmeye aktarılmaktadır. 


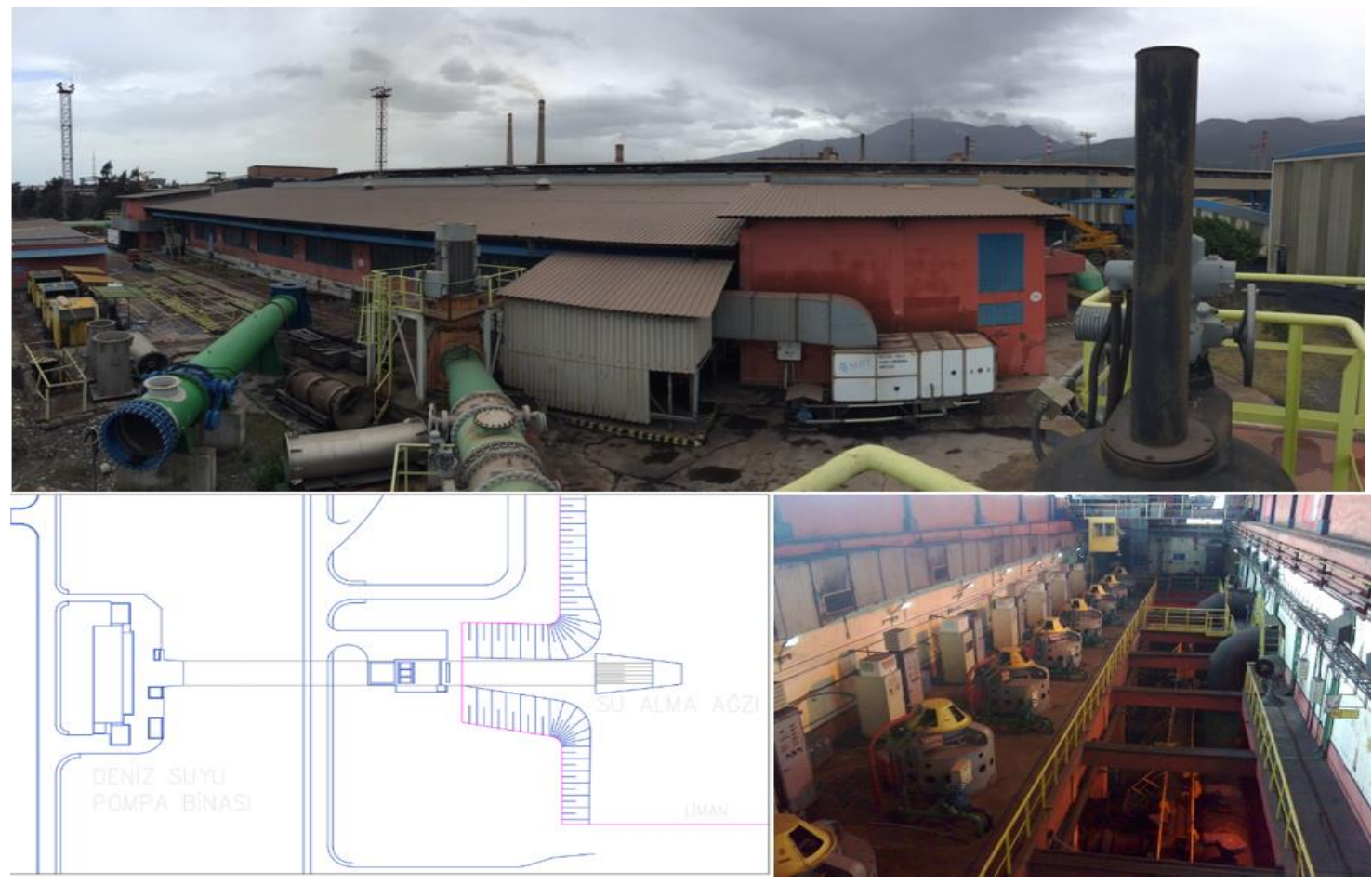

Şekil 1. Tesis genel görünüşü

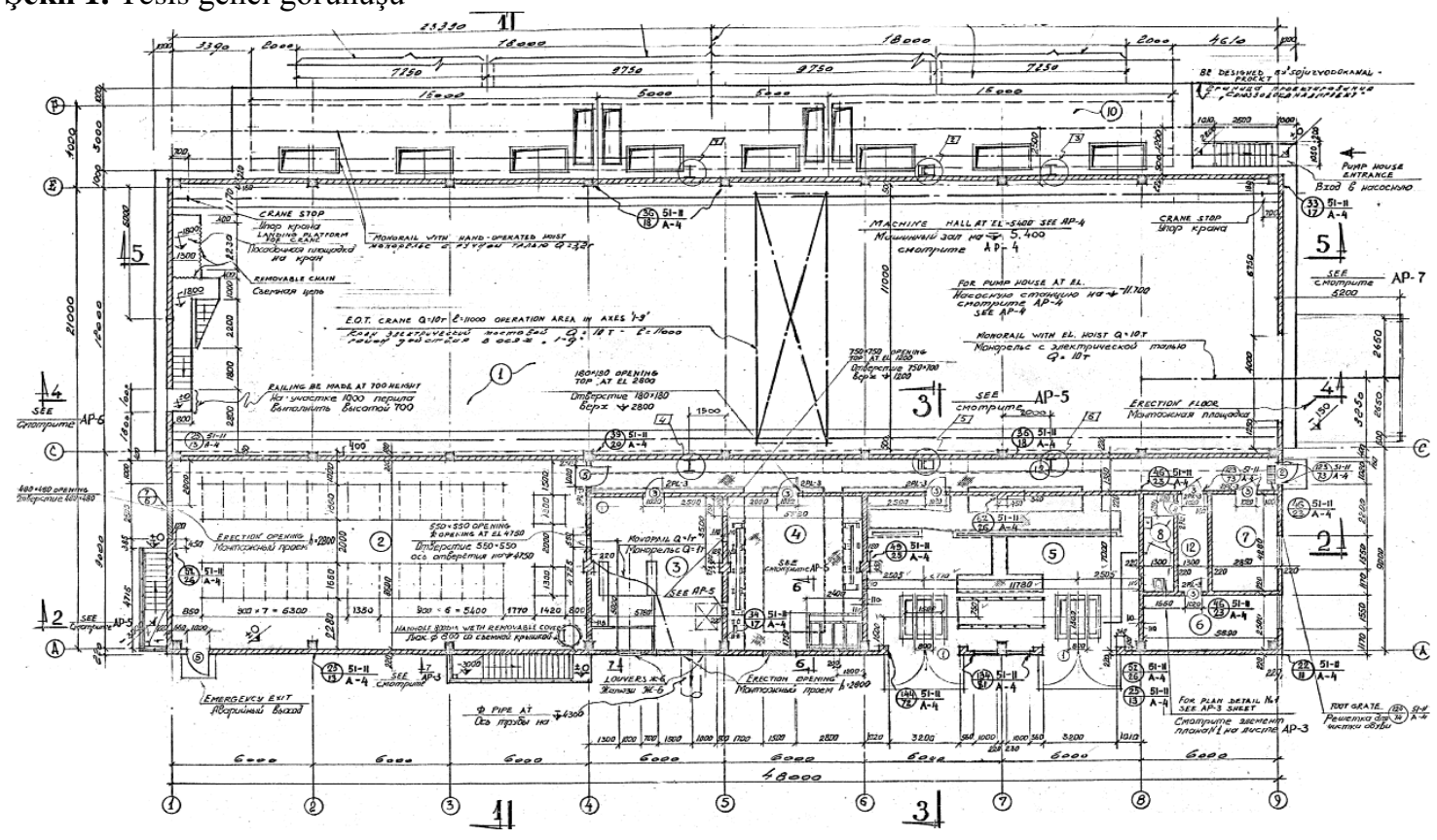

Şekil 2. Tesis $\pm 0,00$ kotu plan 


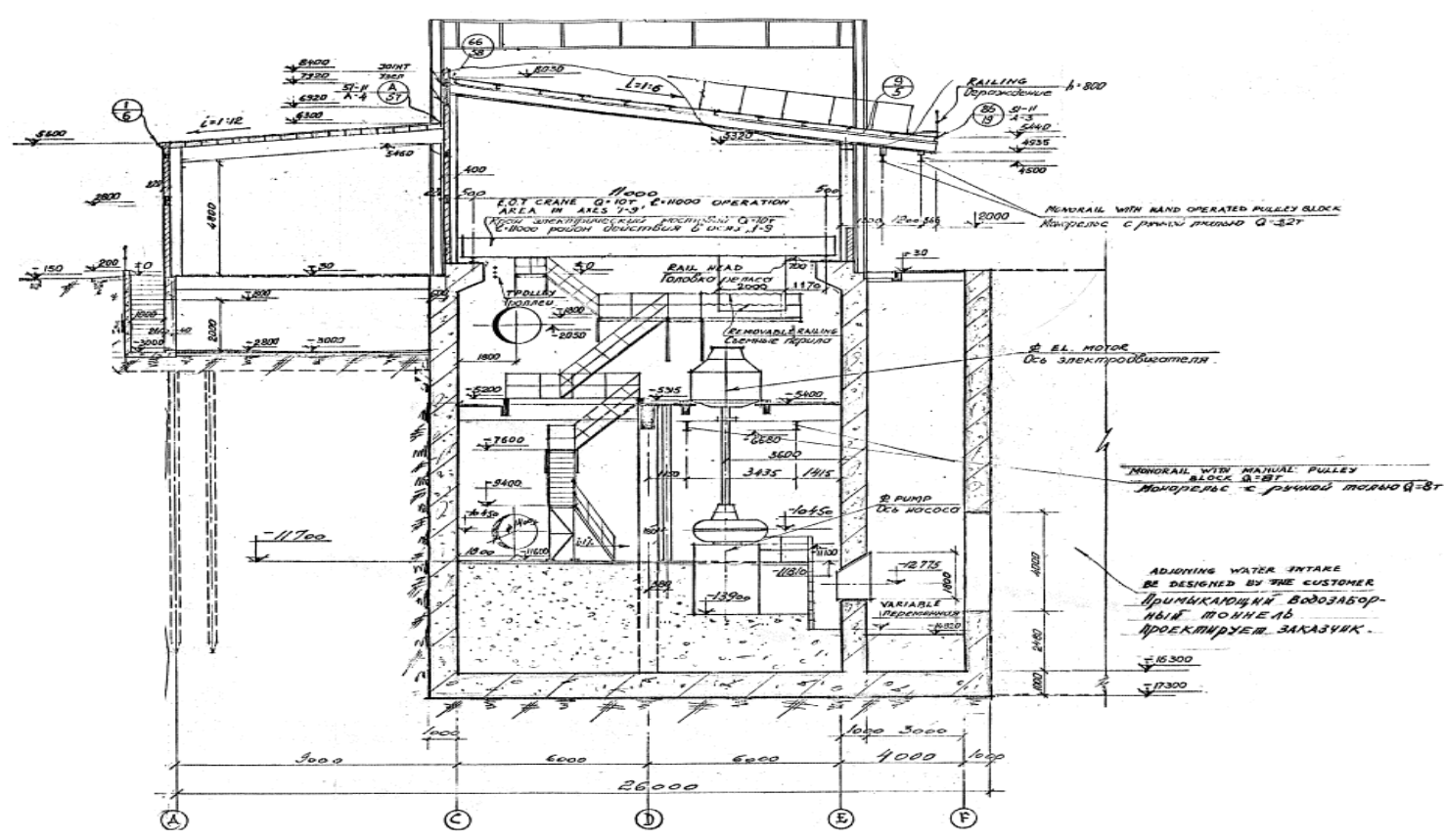

Şekil 3. Tesis kesiti

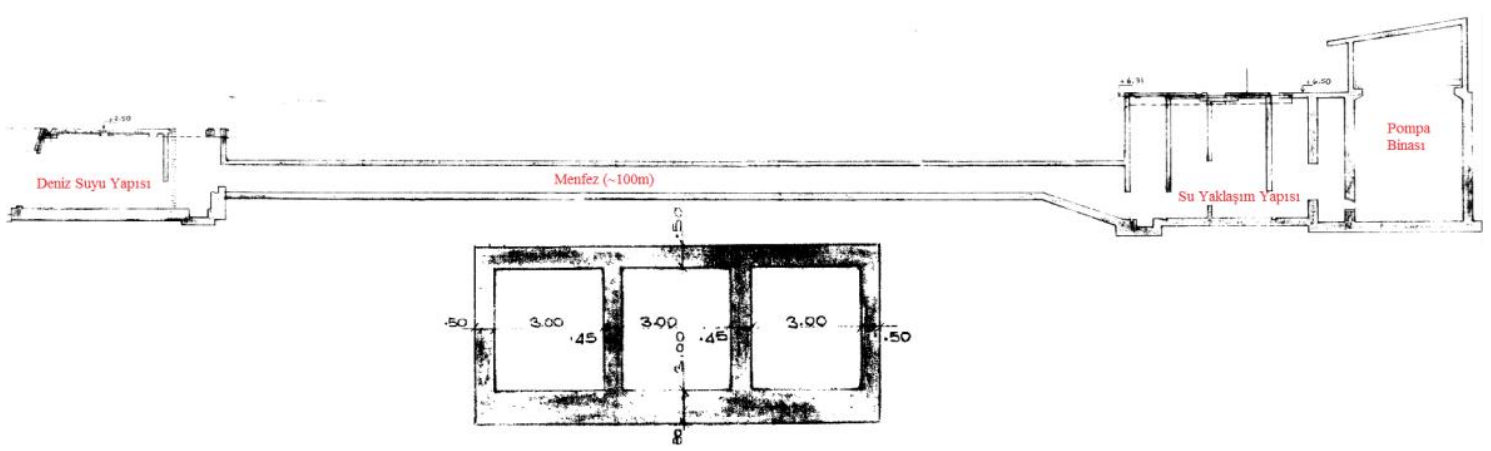

Şekil 4. Menfez kesitleri

\section{MATERYAL VE METOT}

70’li yıllardan günümüze kadar yıpranmış yapının mevcut durum analizi ilgili Türk standart ve yönetmelikleri uyarınca yapılmıştır (TS EN 13791,TDY, TS500, TS498).

Yapılan çalışmalar aşağıda özetlenmektedir:
1- Toplam 6 adet karot numune alınarak mevcut beton kalitesi belirlenmiştir.

2- Betonarme elemanların donatılarında örnekleme metoduyla çap ve adet kontrolleri yapılmış ve yapılan uygulamanın projelerle uygunluğu teyit edilmiştir.

3- $\mathrm{Su}$ kamaralarında dalgıç marifetiyle su altı video ve fotoğraf çekimleri yapılarak kamaraların mevcut durumları incelenmiştir. 
4- Proje bölgesindeki zemin yapısının irdelenmesi amacıyla 5 adet $25 \mathrm{~m}$ derinliğinde sondaj yapılarak bir Geoteknik Rapor hazırlanmıştır.

Mimari projeleri 1978 yilında hazırlanan ve 2004 yılında mevcut binanın yanında inșa edilen ilave yapılar da inceleme çalışmalarına dahil edilmiştir.

Saha çalışmalarında elde edilen veriler ve orijinal projeler kullanılarak incelenen yapılar SAP2000 bilgisayar programı yardımı ile modellenerek analiz edilmiştir. Analizlerden elde edilen kesit tesirleri ile saha çalışmalarında elde edilen veriler değerlendirilerek binalarla ilgili güçlendirme gereksinimleri ve öneriler belirlenmiştir. Binalar ayrica STA4CAD betonarme bina analiz programinda da modellenerek SAP2000 paket programından elde edilen sonuçlar ile karşılaştırılmıştır.

2004 yılında inşa edilen ilave yapılar ise sadece mimari projelerinin bulunmasi sebebiyle STA4CAD programinda modellenerek analiz edilmiştir.

\section{BULGULAR}

\subsection{Saha Çalışmalarından Elde Edilen Veriler}

\subsubsection{Karot Numune Alımları}

İnceleme konusu tüm binaların mevcut beton kalitesinin belirlenmesi için 6 farklı noktadan karot numuneler alınmıştır. Alınan numuneler laboratuvar ortamında basınç testlerine tabi tutularak incelenmiştir.

Alınan 6 adet karot numunenin laboratuvar ortamında yapılan basınç deneylerinden elde edilen dayanım değerleri 18,76 ila $46,43 \mathrm{~N} / \mathrm{mm}^{2}$ arasında değişmektedir. Beton dayanım değerlerinin geniş aralıkta olmasının nedeni pompa istasyonu binası ile eklentilerinin farklı zamanlarda inşa edilmesi olarak düşünülmektedir.

$\mathrm{Su}$ kamarasından alınan numunenin basınç dayanımı 34,32 N/mm² (yaklaşık C30) olarak bulunmuştur. Ancak burada dalgıç marifetiyle yapılan detaylı incelemede pas paylarının yer yer
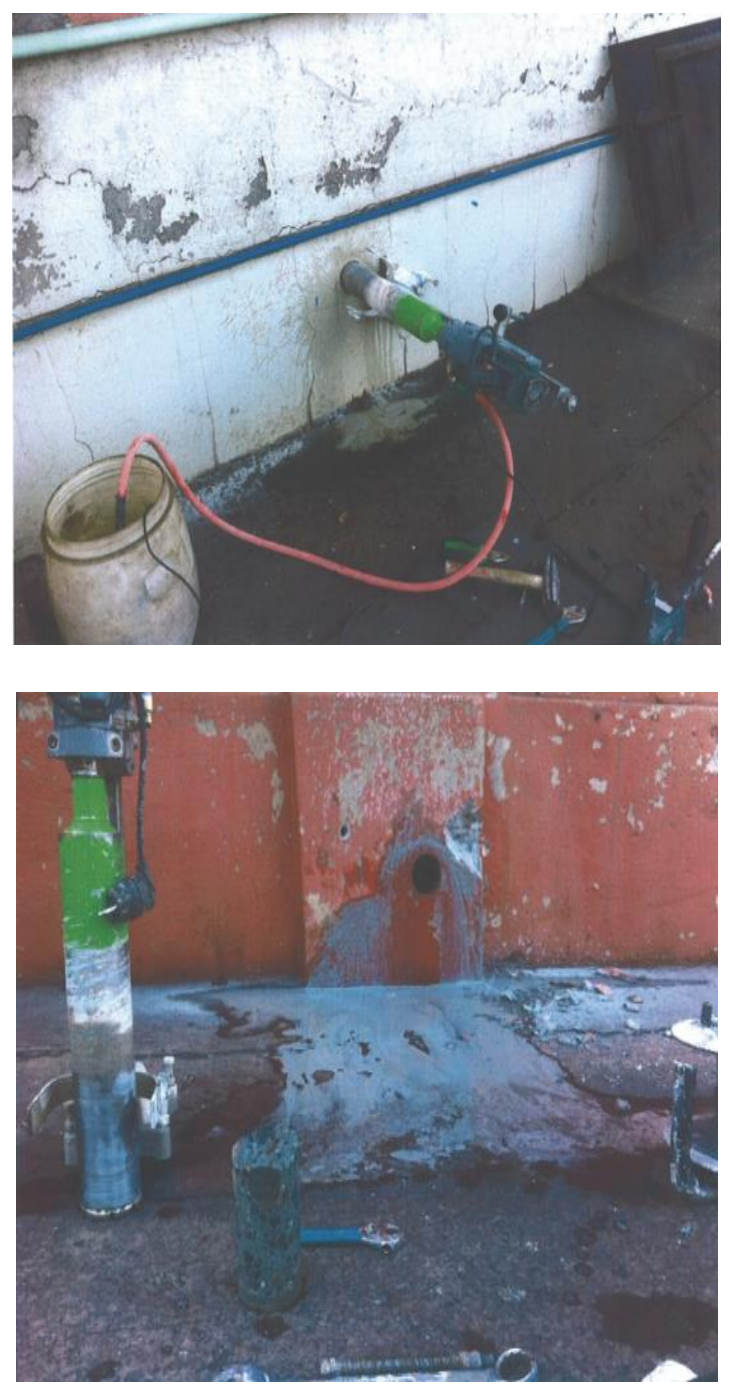

Şekil 5. Karot resimleri

döküldüğü ve numunenin pas payının üzerinde kalan kisımdan alındı̆̆ 1 göz önünde bulundurulmalıdır. $\mathrm{Bu}$ bölgede pas paylarının dökülmüş olması ileriye dönük ciddi bir donatı korozyonu riskini de beraberinde getirmektedir.

Binalardan alınan karot numune sonuçlarına göre her bir binadaki ortalama eşdeğer küp basınç dayanımı aşağıda verilmiştir:

Pompa istasyonu binasi:

$(45,1+34,3+19,39) / 3=32,93$ (C 25)

Kontrol binas1: 46,43 (C 35) 
İlave binalar: $(33,04+18,76) / 2=25,9(\mathrm{C} 20)$

\subsubsection{Betonarme Donatısı Kontrolleri}

Binaların projelerinde verilen betonarme donatılarının çaplarının ve adetlerinin kontrolü seçilen 5 adet betonarme elemanda uygulanan ultrasonografik ve mekanik incelemeler yardımı ile yapılmıştır. Ultrasonografik ölçüm ile elemanın donatı adeti belirlenmiş olup ilave olarak inceleme bölgesinde pas payları sıyrılarak açığa çıkan donatı çeliklerinin çapları ölçülmüştür.

Ultrasonografik ve mekanik inceleme ile epoksi tamir harc1 kullanılarak yapılan onarımlara ait fotoğraflar Şekil 6 ve Şekil 7'de görülmektedir.

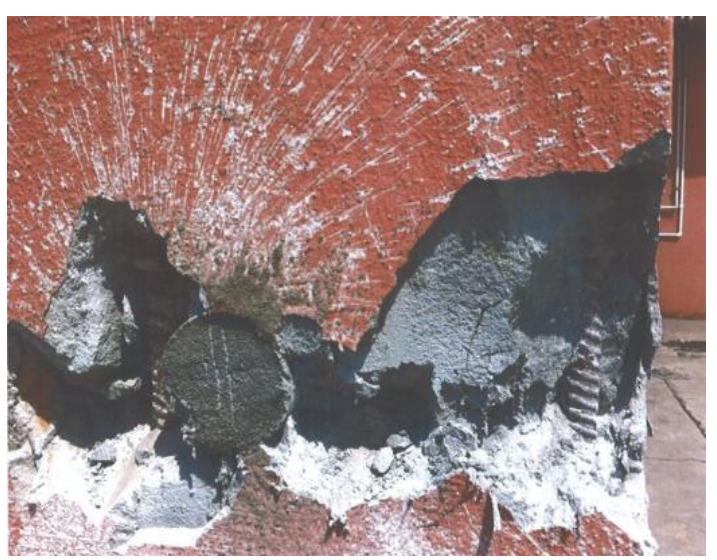

Şekil 6. Donatı tespiti, onarım-1

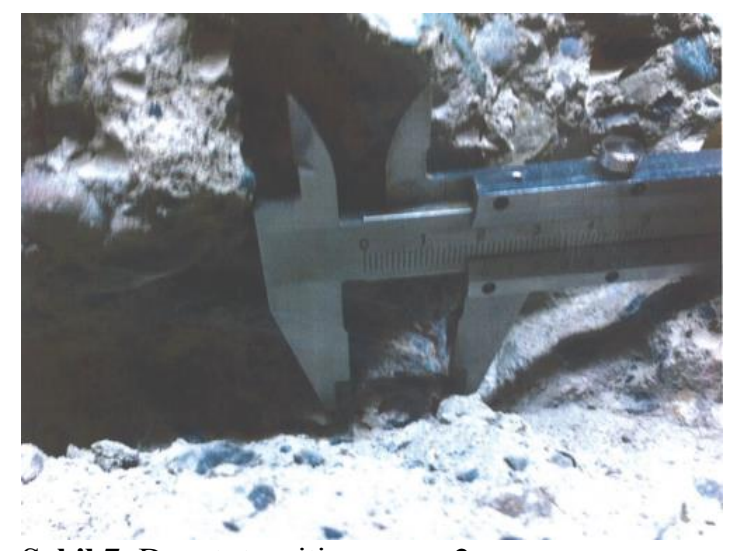

Şekil 7. Donatı tespiti, onarım-2
Yerinde yapılan ölçümlerden elde edilen sonuçlar ile projelerdeki betonarme detayları karşılaştırıldığında aşağıdaki sonuçlar elde edilmiştir;

- Donat1 adetleri ve aralıkları projelerde belirtilenler ile uyumludur.

- Su ile temas etmeyen yüzeylerde donatı korozyonu tespit edilmemiştir. Donatı çapları projelerde belirtilenler ile uyumludur.

- İlave binalar ile ilgili betonarme projeler bulunmadığ 1 için bu binaların betonarme elemanlarının donatı yüzdesi yerinde yapılan incelemelerle uyumlu olarak kabul edilmiştir.

- Su ile temas eden yüzeylerde (su kamaralarının içinde) pas paylarında yer yer dökülmeler ve betonda derin çatlaklar tespit edilmiştir.

Bu veriler 1şığında mevcut projelerdeki donatı adet ve çapları doğru kabul edilerek hesaplar yapılmışıtır.

\subsubsection{Su Altı İnceleme Sonuçları}

Pompa istasyonu binasina hizmet vermekte olan su kamaralarının mevcut durumlarının incelenmesi maksadıyla dalgıç marifetiyle su altında video ve fotoğraf çekimleri yapılmıştır. $\mathrm{Bu}$ inceleme sırasında dalgıçların güvenliklerini gözlemlemek için 3 adet kamaraya pompa operasyonu ile uyumlu olarak farklı zamanlarda dalışlar yapilmıştır.

Özellikle su altındaki kısımlarda daha iyi çekim yapılabilmesi için yer yer midye grupları temizlenmiştir.

Gerek su altı video çekimleri ve gerekse fotoğraf çekimlerinden yapılan incelemeler neticesinde su kamaralarındaki duruma ilişkin değerlendirmeler aşağıdadır;

- Su kamaralarının betonarme duvarlarında ciddi pas payı hasarları ve buna bağlı donatı korozyonları mevcuttur.

- İnşaat sırasında yapılan muhtemel yanlış uygulamalar ve zaman içinde meydana gelen hareketler sonucunda duvarlarda derin çatlaklar meydana gelmiştir. Bu çatlakların betonarme duvarların taşıma gücünü ciddi oranda azalttığı kanaatine varılmıştır. 

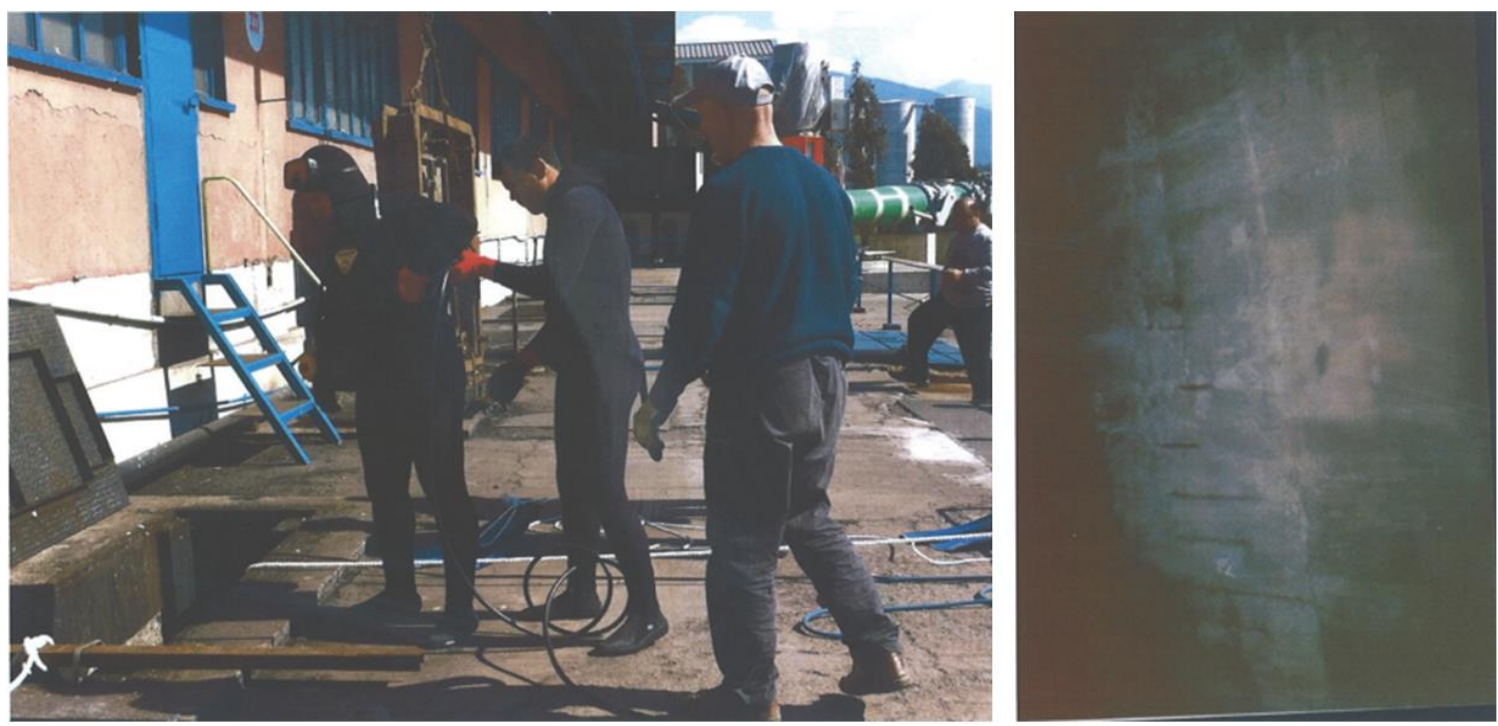

Şekil 8. Su altı durum tespiti

- Su kamaralarının içindeki yardımcı çelik konstrüksiyon elemanlar (giyotin kızakları vb.) korozyon nedeniyle kısmen veya tamamen erimiş ve kullanılamaz hale gelmiştir.

- Projelerde o zaman kullanilan standartlardan kaynaklanan geniş donatı ve etriye aralıkları tespit edilmiştir. Bu durum su kamaralarında yapılan incelemelerde de tespit edilmiştir.

\subsubsection{Geoteknik Rapor Çalışmaları}

Pompa İstasyonu'nun bulunduğu bölgedeki zemin koşullarını belirlemek için binaların çevresinde seçilen 5 adet noktada her biri $25 \mathrm{~m}$ derinliğinde sondajlar yapılmıştır. Sondaj yerleri mevcut mekanik ve elektrik altyapısının elverdiği ölçüde binanın etrafına homojen olarak dağılacak şekilde seçilmiştir.

Sondaj çalışmaları sırasında yerinde yapılan deneyler ve ölçümler ile sondajlardan alınan zemin numunelerinin laboratuvar ortamında deneyleri yapılarak bir zemin etüt raporu hazırlanmıştır.

\subsection{Analiz Çalışmaları}

Yükler

Ölü Yük $(G)$ : Zati Yükler
Çatı Kaplama: Hareketli Yük ile beraber Çatı Kaplama Zati Ağırlığ 1 ( $\left.150 \mathrm{~kg} / \mathrm{m}^{2}\right)$

Q: Hareketli Yükler (Çatıda $100 \mathrm{~kg} / \mathrm{m}^{2}$, Döşemelerde $200 \mathrm{~kg} / \mathrm{m}^{2}$ alınmıştır)

Dolgu Betonu: Bina tabanında kullanılan dolgu betonunun ağırlığı $\left(2,4 \mathrm{t} / \mathrm{m}^{2}\right)$

Dolu Boru: Bina içindeki ana su borusunun ağırlığı. Boru ağırlı̆̆ $(0,69 \mathrm{t} / \mathrm{m})$ ve içindeki suyun ağırlığ $1(1,539 \mathrm{t} / \mathrm{m})$ beraber $(2,23 \mathrm{t} / \mathrm{m})$ alınmıştır. $\mathrm{Bu}$ ağırlık $40 \mathrm{~cm}$ genişliğindeki döşeme şeridine yayılı yük $\left(2,23 / 0,4=5,575 \mathrm{t} / \mathrm{m}^{2}\right)$ olarak etki ettirilmiştir.

Pompa: 8 adet pompanın ağırlıkları (Her biri 7,5 ton alınmıştır)

Rüzgar ve deprem yükleri, yürürlükteki yönetmeliklere göre girilmiştir. Bina perdelerine etkiyen dinamik toprak basıncı ve bina üstyapısına etkiyen eşdeğer deprem kuvveti alan yükü (area load) olarak etki ettirilmiştir. Bu yükler 0 ila $23 / \mathrm{m}^{2}$ arasında değişen değerler olarak hesaplanmıştır.

\section{Rüzgar Yükü: \\ Rügar Hızı: $(0-8 \mathrm{~m}$ arası için) $28 \mathrm{~m} / \mathrm{sn}$ $\mathrm{q}=0,5 \mathrm{kN} / \mathrm{m}^{2}$}

Düzlemsel yüzeylerle sınırlandırılmış yapı elemanlar1: $\mathrm{C}=1,2$ 


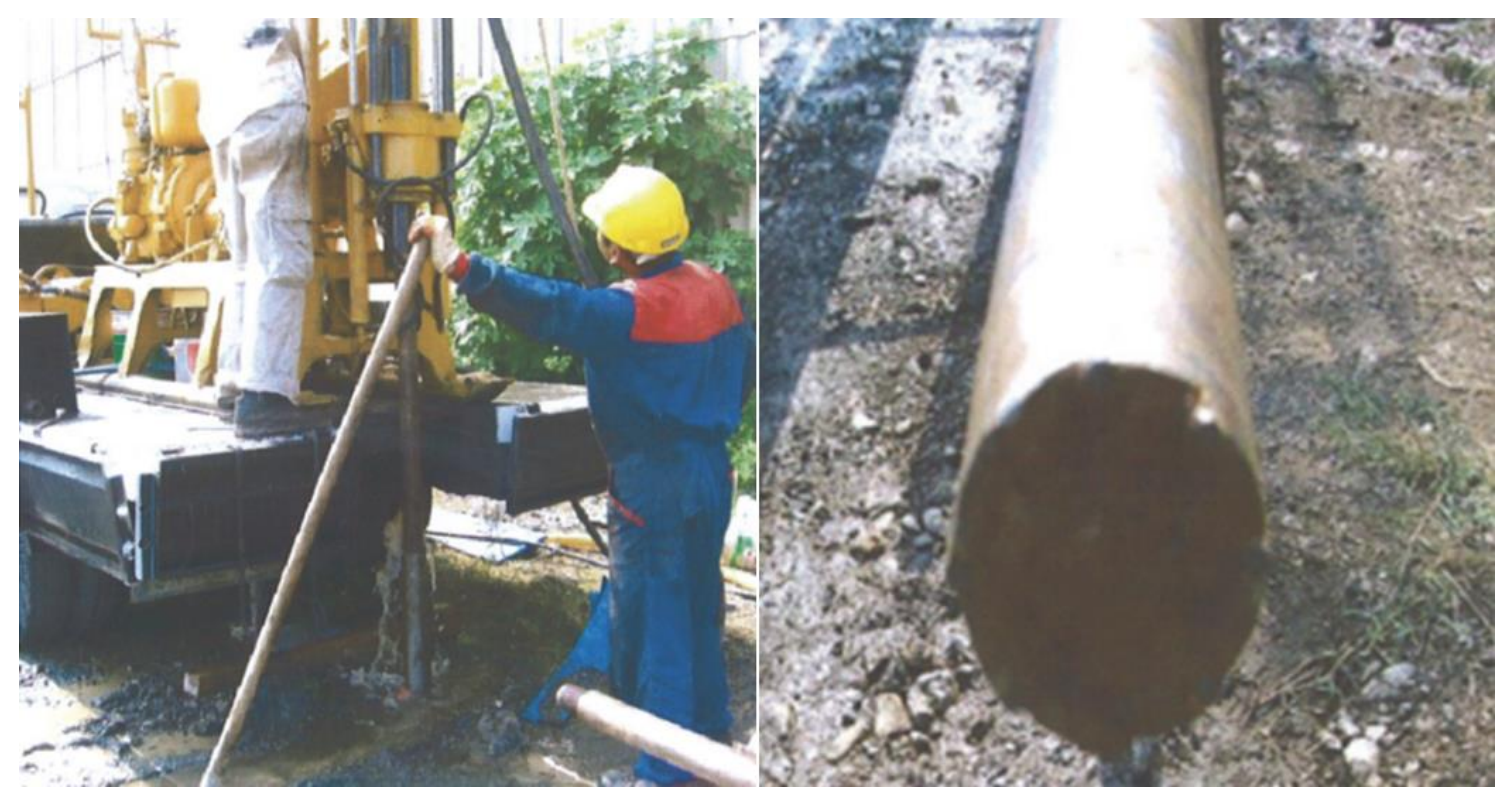

Şekil 9. Geoteknik rapor çalışmaları

Rüzgar Kuvveti: $1,2 \times 0,5=0,6 \mathrm{kN} / \mathrm{m}^{2}=0,06 \mathrm{t} / \mathrm{m}^{2}$

Basıç: $0,8 \times 0,06=0,048 \mathrm{t} / \mathrm{m}^{2}$

Emme: $0,4 \times 0,06=0,024 \mathrm{t} / \mathrm{m}^{2}$

Çatıya Etkiyen Eşdeğer Deprem Kuvveti:

$\mathrm{T}(1)$ : 0,66 sn (Y - Enine Yön)

$\mathrm{T}(1)>\mathrm{T}(\mathrm{B})=0,40 \mathrm{sn}$

Deprem Bölgesi: 1

Etkin Yer İvmesi: 0,4g

Yapı Önem Katsayısı: 1,5

Süneklik Düzeyi Normal Sistem koşulu geçerli $(\mathrm{b} / 2 \mathrm{t}<0,5 \sqrt{ }($ Es/ $/ \mathrm{a}))$

$0,5 \sqrt{ }\left(2,1 \times 10^{6} / 2400\right)=14,79$

$\mathrm{b} / 2 \mathrm{t} \quad \mathrm{I} 400=14,01$

Buna göre $\mathrm{R}=5$

$\mathrm{S}(\mathrm{T})=2,5 \times(0,4 / 0,66)^{\wedge} 0,8=1,675$

$\mathrm{A}(\mathrm{T})=0,4 \times 1,5 \times 1,675=1$

$\mathrm{W}=299$ ton $($ SAP2000'den $)$

$\mathrm{Vt}=(299 \times 1) / 5=59,8$ ton

$\mathrm{T}(2)$ : 0,151 sn (X - Boyuna Yön)
$\mathrm{R}=5, \mathrm{~S}(\mathrm{~T})=2,5, \mathrm{~A}(\mathrm{~T})=0,4 \times 1,5 \times 2,5=1,5$

$\mathrm{W}=642,24$ ton (SAP2000'den) (hareketli yük dahil)

$\mathrm{Vt}=(299 \times 1,5) / 5=89,7$ ton

Sükunetteki toprak basıncı depremsiz ve depremli halde hesap edilerek modele etki ettirilmiştir.

Depremli haldeki toprak basıncı hesabında DLH 2008 Deprem Teknik Şartnamesinde verilen hesap yöntemi kullanılmıştır. Her iki durum için oluşan toprak basıncı diyagramları aşağıda verilmiştir.

Düşey eksen $\mathrm{m}$ cinsinden derinliği gösterirken yatay eksen $\mathrm{t} / \mathrm{m}$ cinsinden toprak basincinı göstermektedir:

\subsection{Model Çalışmaları}

Pompa istasyonu binas1 SAP2000 bilgisayar programında modellenirken yukarda bahsedilen yükler kullanılmıştır. 

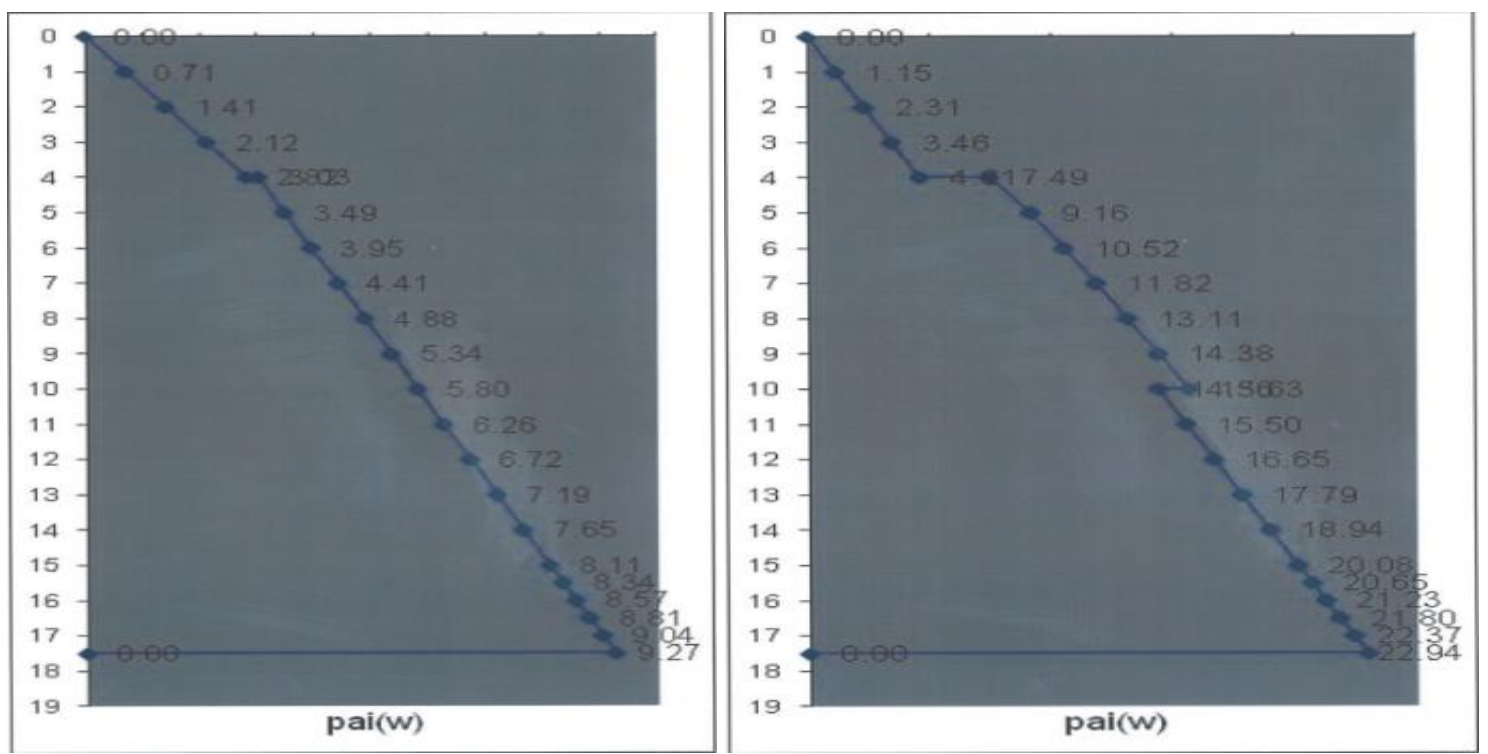

Şekil 10. Sükunetteki toprak basınç diyagramı (depremsiz ve depremli durum)

Analiz sonucunda elde edilen kesit tesirlerine göre binayı oluşturan taşıyıcı elemanların (betonarme kolon, betonarme perde, betonarme kiriş, çelik kolon, çelik kiriş vs.) kesit ve donatı ihtiyaçları irdelenerek mevcut durumla karşılaştırılmıştır.

Ayrıca mevcut yapı STA4CAD bilgisayar programı ile de modellenmiştir. Yapılan incelemede STA4CAD bilgisayar programı ile yapılan analizden elde edilen sonuçlarla SAP2000 bilgisayar programı ile yapilan analizden elde edilen sonuçların uyumlu olduğu görülmüştür.

Pompa istasyonu binası için oluşturulan STA4CAD bilgisayar programı modeli ile SAP2000 bilgisayar programı modelinin görünümleri Şekil 11 'de sunulmuştur.

Gerek işletme durumu ve gerekse deprem durumundaki yüklemeler için $-16,30 \mathrm{~m}$ ve -11,70 m kotları arasında dökülmüş olan BS120 dolgu betonunun etkisi de göz önünde bulundurulmuştur.

Sonuç olarak, toprak perdelerinde oluşan eğilme momenti değerleri mevcut taşıma kapasiteleri sınırları içinde kalmaktadır. Söz konusu dolgu betonunun modellenmesi Şekil 12'de görülmektedir.

\subsubsection{Taban plağı -Zemin Etkileşimi}

Taban plağının altında hazırlanan zemin etüt raporu doğrultusunda zemin için 10,000 t/ $\mathrm{m}^{2}$ lik bir yatak katsayısı tanımlanmıştır.

Ayrıca modelin stabilitesinin sağlanması amacıyla bina tabanının 4 köşesindeki düğüm noktalarında $\mathrm{x}$ ve y yönündeki yatay deplasmanlar tutulmuştur.

Analiz sonucunda taban plağı düğüm noktalarındaki maksimum deplasman değeri $0,003299 \mathrm{~m}$ olarak belirlenmiştir. Buna göre taban plağı altındaki maksimum gerilme 1,33 deprem azaltma katsayısı göz önünde bulundurularak:

$0,003299 \times 10,000 / 1,33=24,99 \mathrm{t} / \mathrm{m}^{2}<$ Zem $=$ $40 \mathrm{t} / \mathrm{m}^{2}$ sonucuna varılmıştır. Burada bina içindeki dolgu betonunun taban plağı ile etkileşimi ve plağın eğilme rijitliğine katkısı zemin gerilmelerinin sınırlandırılmasında etkili olmuştur. 
Denizden Su Alma Yapısı ve Binası Performans Analizi ve Güçlendirilmesi
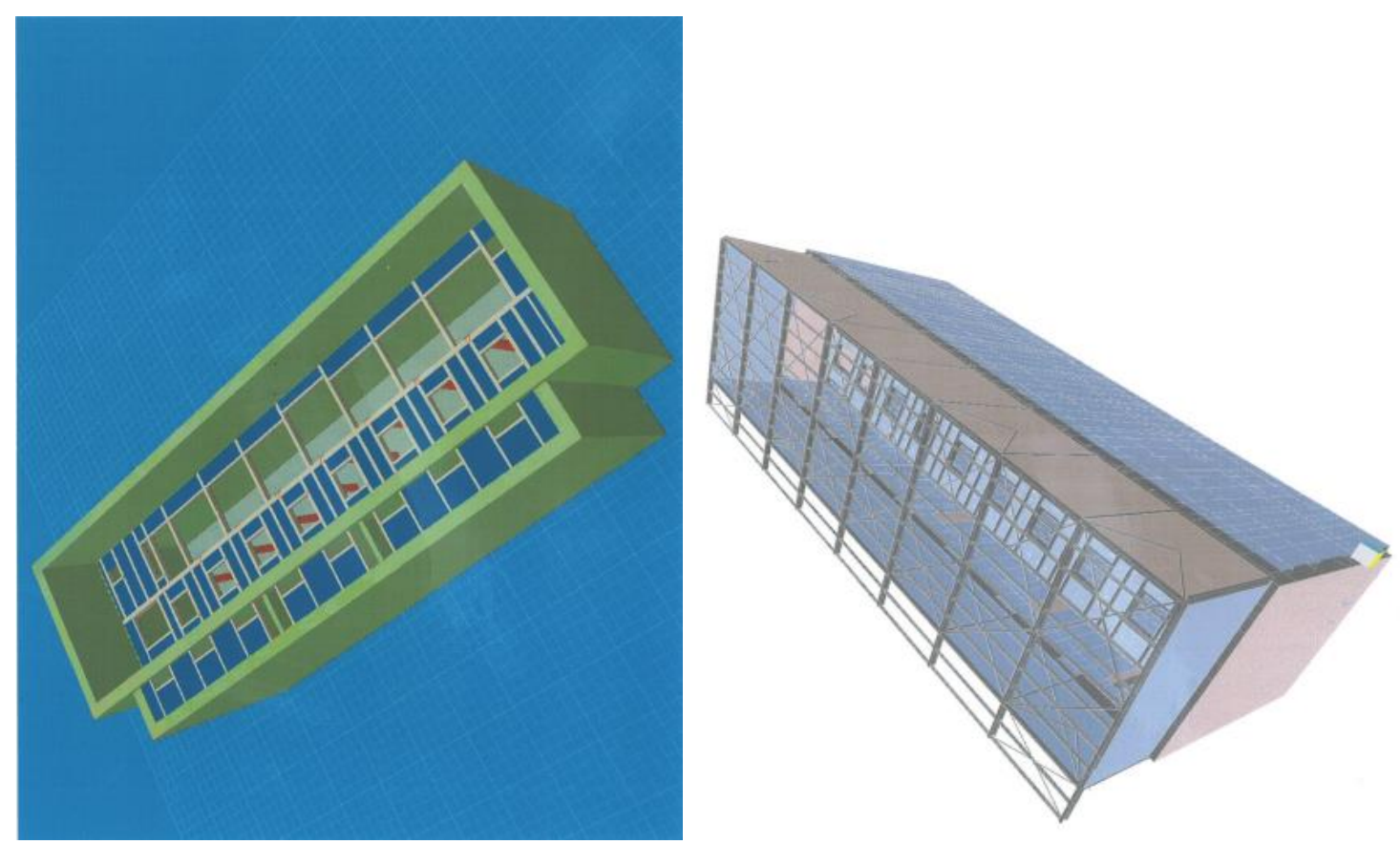

Şekil 11. STA4CAD ve SAP2000 modelleri

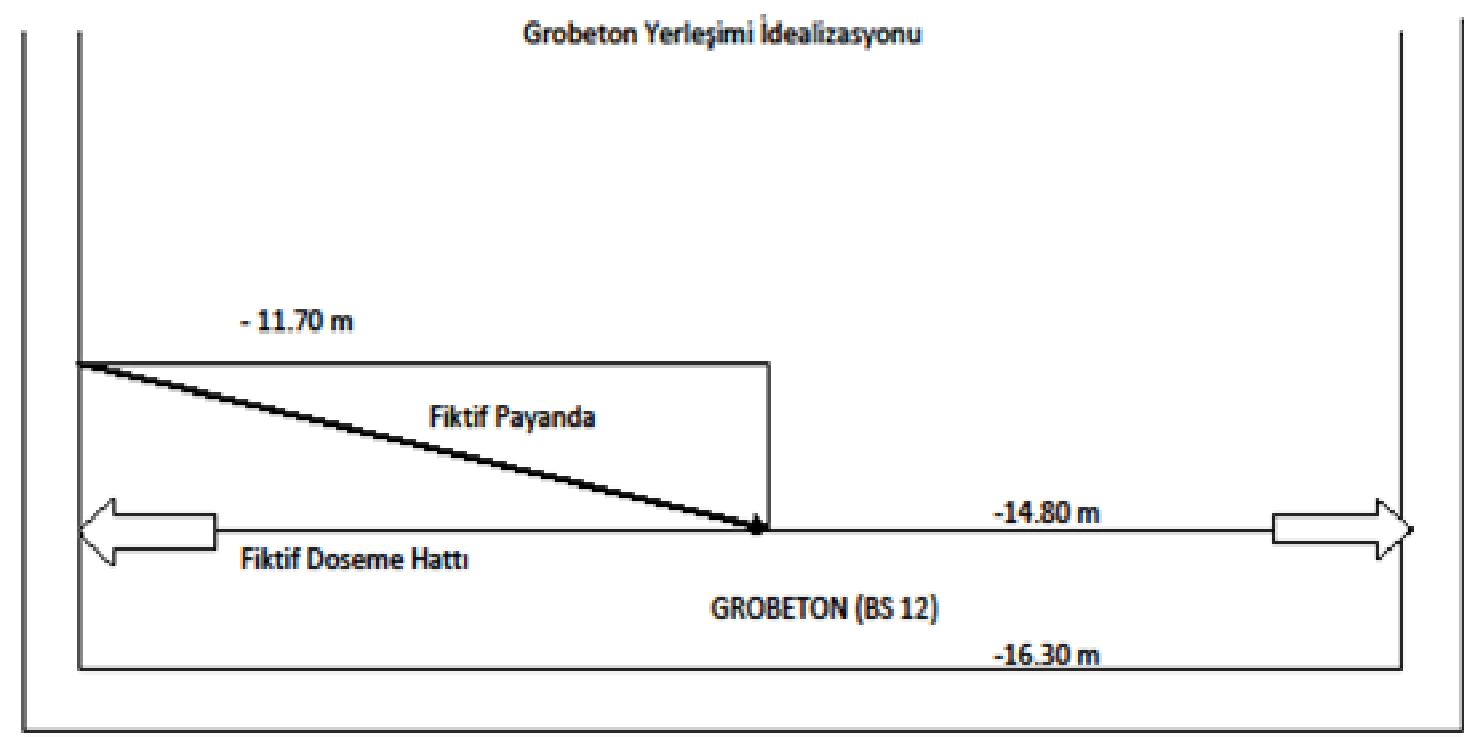

Şekil 12. Grobeton idealizasyonu 
Çizelge 1. Perde moment taşıma kapasitesi

\begin{tabular}{|l|c|l|c|c|}
\hline \multicolumn{1}{|c|}{ Perde Konumu } & Donatı Yönü & Donatı & $\begin{array}{c}\text { İşletme Durumu } \\
\text { (Tm) }\end{array}$ & $\begin{array}{c}\text { Deprem Durumu } \\
\text { (Tm) }\end{array}$ \\
\hline Kara T. Bina Perdesi & Düşey & $\varnothing 25 / 20$ & 54 & 70 \\
\hline Kara T. Bina Perdesi & Yatay & $\varnothing 20 / 10$ & 68 & 89 \\
\hline Deniz T. Bina Perdesi & Düşey & $\varnothing 20 / 20$ & 35 & 45 \\
\hline Deniz T. Bina Perdesi & Yatay & $\varnothing 20 / 10$ & 68 & 89 \\
\hline Su Kam. Dış Perdesi & Düşey & $\varnothing 25 / 20$ & 54 & 70 \\
\hline Su Kam. Diş Perdesi & Yatay & $\varnothing 25 / 10$ & 105 & 136 \\
\hline Bina Yan Perdeleri & Düşey & $\varnothing 25 / 20$ & 54 & 70 \\
\hline Bina Yan Perdeleri & Yatay & $\varnothing 20 / 20$ & 35 & 45 \\
\hline
\end{tabular}

\subsubsection{Betonarme Kolonlar}

Binanın içinde bulunan $50 \times 50 \mathrm{~cm}$ ebatlarındaki betonarme kolonlarda oluşan kesit tesirleri analiz sonuçlarından belirlenmiştir. Söz konusu ebatlardaki kolonların hesap sonucu elde edilen kesit tesirlerine göre ihtiyacı olan donatı adetleri STA4CAD bilgisayar programının tekil kolon hesabı modülü ile belirlenmiştir. Yapılan hesap sonucunda kolonlardaki mevcut donatıların yetersiz olduğu ve güçlendirme ihtiyacının bulunduğu görülmüştür (Çizelge 2).

Çizelge 2. Betonarme kolon karşılaştırması

\begin{tabular}{|c|c|c|c|c|c|c|}
\hline Kolon & N & $\mathbf{M}$ & $\mathbf{V}$ & $\begin{array}{c}\text { Beton } \\
\text { Sinıfi }\end{array}$ & $\begin{array}{c}\text { Mevcut } \\
\text { Donatı }\end{array}$ & Gereken Donatı \\
\hline K1 (50/50) & 33,1 & 3,7 & 0,6 & C25 & $10 \varnothing 16$ & $14 \varnothing 16$ \\
\hline K2 (50/50) & 45,9 & 2,5 & 0,23 & C25 & $10 \varnothing 16$ & $14 \varnothing 16$ \\
\hline K3 (50/50) & 41,3 & 2,7 & 0,23 & C25 & $10 \varnothing 16$ & $14 \varnothing 16$ \\
\hline K4 (50/50) & 41,9 & 3,0 & 0,3 & C25 & $10 \varnothing 16$ & $14 \varnothing 16$ \\
\hline K5 (50/50) & 41,8 & 2,9 & 0,3 & C25 & $10 \varnothing 16$ & $14 \varnothing 16$ \\
\hline K6 (50/50) & 42,1 & 2,9 & 0,3 & C25 & $10 \varnothing 16$ & $14 \varnothing 16$ \\
\hline K7 (50/50) & 41,9 & 2,5 & 0,3 & C25 & $10 \varnothing 16$ & $14 \varnothing 16$ \\
\hline K8 (50/50) & 43,3 & 2,2 & 0,15 & C25 & $10 \varnothing 16$ & $14 \varnothing 16$ \\
\hline K9 (50/50) & 56,5 & 2,3 & 0,2 & C25 & $10 \varnothing 16$ & $14 \varnothing 16$ \\
\hline
\end{tabular}

\subsubsection{Betonarme Kirişler}

Analiz sonucunda betonarme kirişlere etkiyen kesit tesirleri elde edilmiştir. Bu değerlere göre kirişler için gerekli olan donatı miktarları STA4CAD programının tekil kiriş hesabı modülü ile belirlenmiştir.
Yapılan hesap sonucunda kirişlerdeki mevcut donatıların yeterli olduğu ve güçlendirme ihtiyacının bulunmadığı görülmüştür. Aynı șekilde kirişler arasında bulunan ve tabla görevi gören döşemelerde de sorun teşkil edecek bir durum olmadığ görülmüştür (Çizelge 3). 


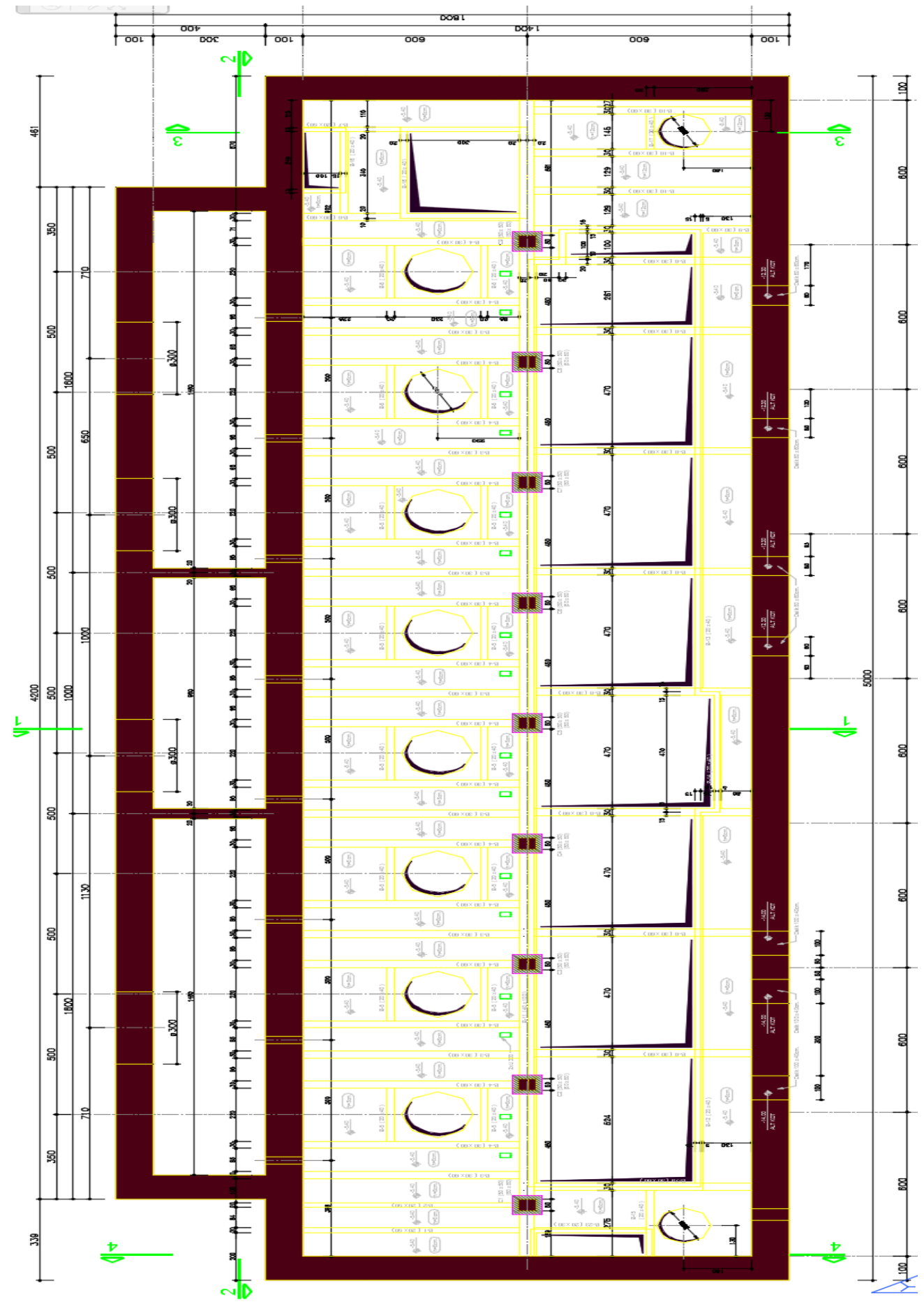

Şekil 13. Güçlendirme teknik detayları-1 

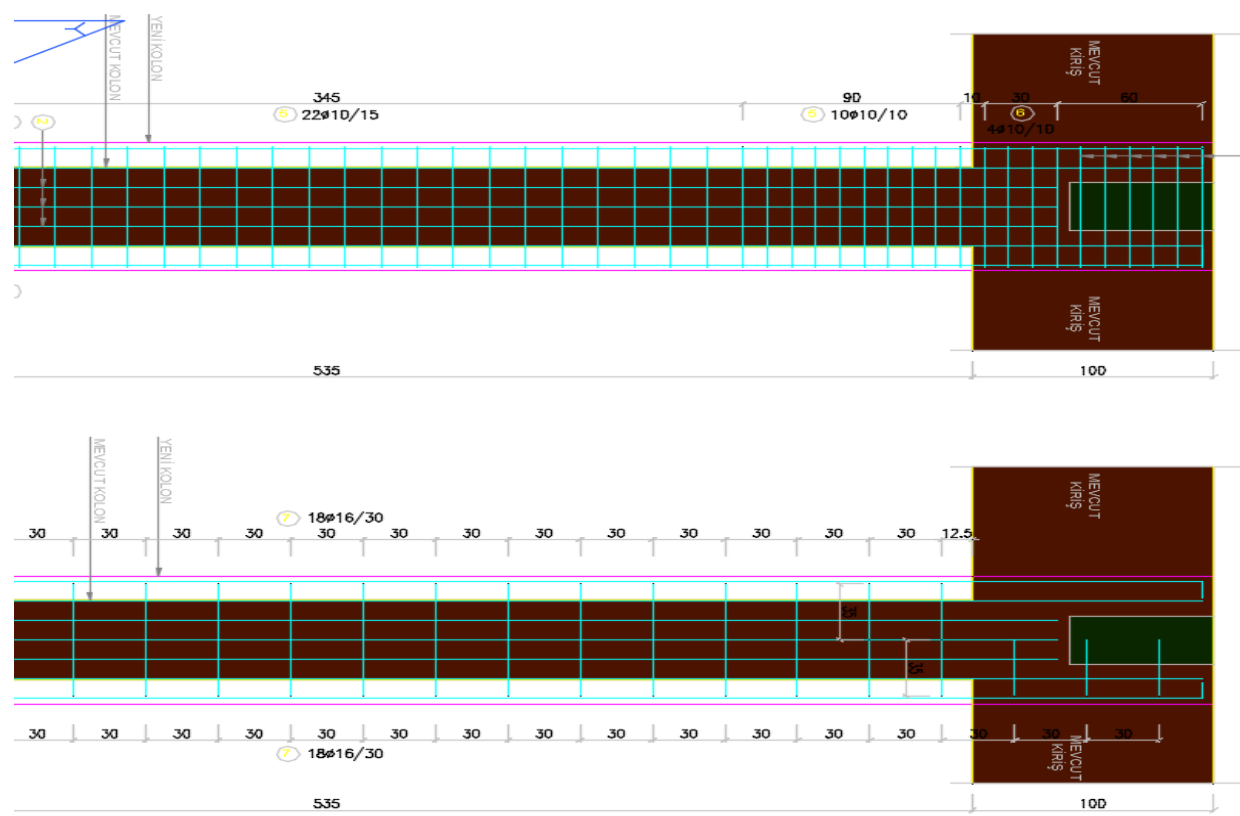

535

100

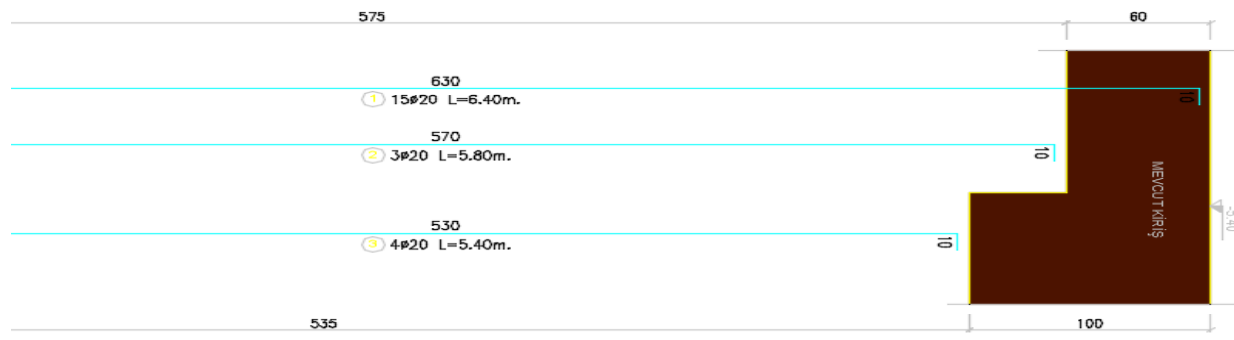

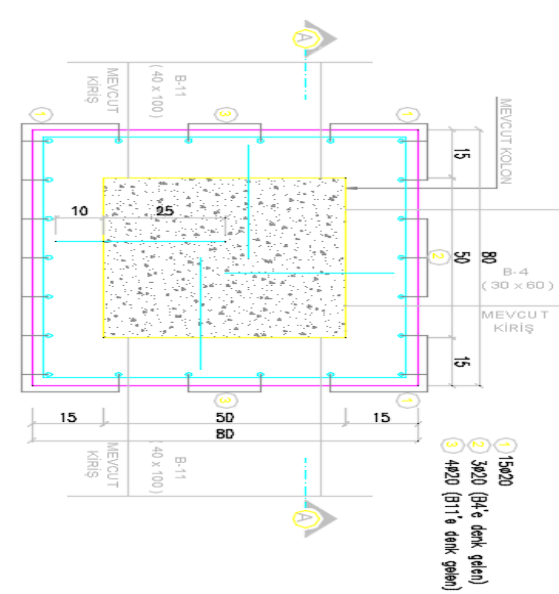

Şekil 14. Güçlendirme teknik detayları-2

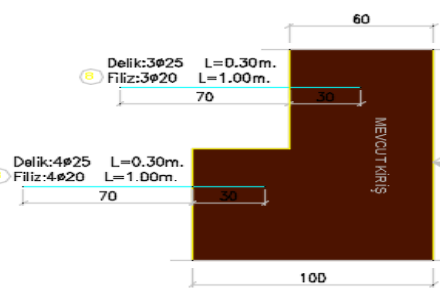

100 
Çizelge 3. Betonarme kiriş karşılaştırması

\begin{tabular}{|c|c|c|c|}
\hline Kiriş & Beton & Mevcut Donatı & Gereken Donatı \\
\hline B (20/60) & C25 & $4 \varnothing 18$ & $3 \varnothing 12$ \\
\hline B (30/60) & C25 & $4 \varnothing 25$ & $5 \varnothing 14$ \\
\hline B (20/40) & C25 & $4 \varnothing 18$ & $2 \varnothing 12$ \\
\hline B (20/50) & C25 & $2 \varnothing 25$ & $3 \varnothing 12$ \\
\hline B (40/100) & C25 & $4 \varnothing 22$ & $10 \varnothing 12$ \\
\hline
\end{tabular}

\section{SONUC}

Su kamaralarının duvarları deniz suyunun zararlı etkilerinden ciddi biçimde etkilenmiştir. $\mathrm{Bu}$ bölümde gerek duvarlarda ve gerekse üst döşemenin alt kısımlarında pas payı dökülmeleri ve donatı korozyonu gözlemlenmiştir.

Yapılan saha incelemesi sonucunda su kamaralarının betonarme duvarlarında ve döşemelerinde irili ufaklı hasarların bulunduğu ve bu kısımların rehabilite edilmesi gerektiği gerçeği ortaya çıkmıştır.

Pompa istasyonu perde duvarları güncel şartnamelerde verilen yükler ve kriterler açısından yeterli bulunmuştur. Pompa istasyonu perde duvarlarında herhangi bir ilave önlem alınmasına gerek duyulmamıştır.

Pompa istasyonu betonarme kolonlarında donatı çap ve adetleri (donatı oranı) yetersiz bulunmuştur. Betonarme mantolama yöntemi ile güçlendirme yapılması gerektiğine karar verilmiştir.

Pompa istasyonu betonarme kirişleri ve döşemelerinde mevcut kesit alanları ve donatı oranları yeterli bulunmuştur.

Yetersiz kesitler için hazırlanan uygulanacak çizim detayları Şekil 13,14'de verilmiştir.

\section{KAYNAKLAR}

1. Galal, K., Arafa, A., Ghobarah A., 2005. Retrofit of RC Square Short Columns, Engineering Structures, Volume 27, No. 5, pages 801-813, April.

2. Minafo, G., 2015. A Practical Approach for the Strength Evaluation of RC columns Reinforced with RC Jackets," Engineering Structures, Volume 85, pages 162-169.

3. Teknik Rapor, 2011. Pompa İstasyonu Mecvut Durumunun Statik Yönden İncelenmesi.

4. TS 500, 2000. Betonarme Yapıların Tasarım ve Yapım Kuralları, Türk Standartları Enstitüsü, Ankara

5. TS EN 13791, 2010. Basınç Dayanımının Yapılar ve Ön Dökümlü Beton Bileşenlerde Yerinde Tayini, Türk Standartları Enstitüsü, Ankara

6. TS 498, 1997. Yap1 Elemanlarının Boyutlandırılmasında Alınacak Yüklerin Hesap Değerleri, Türk Standartları Enstitüsü, Ankara

7. DLH Kıyı ve Liman Yapıları, Demiryolları, Hava Meydanları İnşaatları Deprem Teknik Yönetmeliği, T.C. Ulaştırma Denizcilik ve Haberleşme Bakanlığı, 2008.

8. Deprem Bölgelerinde Yapılacak Binalar Hakkında Esaslar, Çevre ve Şehircilik Bakanlığı, 2007. 